\title{
ALIMENTARY GRANULOMATA AND THE. IMMUNE RESPONSE
}

\author{
G. Slaney, M.S., M.B., Ch.B., F.R.C.S. \\ Department of Surgery, Queen Elizabeth Hospital, Birmingham
}

ThE possible ætiological relationship between the alimentary granulomata and the immune response is one of the more recent and exciting developments in the sphere of gastroenterology.

\section{General aspects}

Although the basic features of the antigenantibody type of response have been well recognized for many years, these processes were hitherto considered to be essentially protective in nature and concerned with ensuring survival under adverse conditions. Recently, however, there has been increasing evidence that under certain circumstances antigen-antibody reactions may play an important ætiological role in diseases whose pathogenesis was previously obscure and shrouded in medical mystery. Of especial interest are the auto-immune disorders in which an individual tissue becomes antigenic, thus stimulating the production of a circulating antibody, the subsequent reaction resulting in destruction or atrophy of the parent tissue concerned. There is good evidence that the collagen diseases arise as the result of such an immune type of response and it has been shown, using fluorescent staining techniques, that the tissue lesions in these diseases are the site of an antigen-antibody reaction (Vazquez and Dixon, 1957). Antibodies to thyroid tissue have been demonstrated in the sera of patients with Hashimoto's disease and chronic thyroiditis (Witebsky, Rose, Terplan, Paine and Egan, 1957; Witebsky, Rose and Shulman, 1958). Auto-antibodies have also been demonstrated in the sera of patients with viral hepatitis, primary biliary cirrhosis, glomerulo-nephritis and the nephrotic syndrome (Mackay, 1958; Gajdusek, 1958; Lui and McCrory, 1958).

A notable feature is the frequency with which certain immunological reactions are associated with a granulomatous type of response. There is now strong experimental and clinical evidence to indicate that polyarteritis nodosa is caused by an immune-hypersensitivity mechanism. Germuth (1953) showed that giving a large dose of bovine serum intravenously in rabbits produced wide- spread cardiovascular and renal lesions resembling those of rheumatic fever, polyarteritis nodosa anc acute glomerulo-nephritis respectively in man: furthermore many of these animals developed widespread granulomatous lesions. Fulminating y. peri-arteritis nodosa with a fatal outcome has beenis recorded following the administration of antiserum and sulphonamides to patients (Rich, 1942); it hasं also occurred in patients with hypersensitivity to drugs such as iodine and arsenic. As in poly-? arteritis nodosa it is possible that immunologicalfactors are also involved in sarcoidosis for Refvem (1954) has shown that in animals sensitized to phospholipid an immune response of the Arthose type occurs with the formation of granulomat? containing giant cells and Schaumann inclusigno bodies, the classical histological features of human sarcoidosis. Wegener's granulomatosis is a rare fatal disease characterized by necrotizing granulomatous lesions in the respiratory tract, generalized vasculitis and a necrotizing glomerulitis (Wegener, 1939); the vascular lesions are identical with those of polyarteritis nodosa. Most are agreed that this disease is a hypersensitivity state; the initial lesiono develops in the nose or paranasal sinuses and is later followed by a generalized hypersensitivity 3 reaction and death from respiratory or renal failure.

\section{Alimentary Involvement in Systemic Disease}

The alimentary tract may be involved in many? of these systemic diseases which arise on an im-o munological basis; such involvement, however, is usually secondary though granulomatous ulcera-o tion, hæmorrhage and perforation frequently result.

In Wegener's granulomatosis extensive granulo- $N$ matous ulceration showing giant cells, fibrosis and central necrosis occurs in the mouth, œsophaguso and small intestine and multiple granulomata are frequently present in the liver and spleen (Codman and Churg, 1954; Walton, 1958; Felson and? Braunstein, 1958).

Forty per cent. of patients with systemic lupuso erythematosis have widespread ulceration in the œsophagus, small bowel and colon due to col-बत्ष 
lagenous degeneration and thrombosis in small vessels (Dubois, 1953). The œsophagus is commonly involved in scleroderma with resulting œsophagitis and ulceration due to incompetence of the cardia; involvement of the small bowel produces secondary sacculation and dilatation, and steatorrhœa may be gross (Abrams, Carnes and Eaton, 1954; Hale and Schatzki, 1944; Rosenthal, 1957). Rarely, colonic changes may be extremely severe resembling fulminating ulcerative colitis and frank gangrene has been reported (Lushbaugh, Rubin and Rothman, 1948).

Patients with dermatomyositis have a high incidence of stomatitis, glossitis and gastro-intestinal ulceration; hæmorrhage and perforation are frequent (Wainger and Lever; I949; Domzalski and Morgan, 1955). There is also a high incidence of malignant disease, including gastro-intestinal cancer, in this condition; the relationship is so constant that a continuing search for malignancy is indicated in every patient with dermatomyositis (Curtis, Blaylock and Harrell, 1952; Dowling, 1955).

Intestinal involvement occurs in over half the cases of polyarteritis nodosa and symptoms are usually due to ulceration, infarction, perforation or hæmorrhage. If ulceration is widespread severe steatorrhœe and malabsorption syndromes result; the mucosa usually shows typical granulomatous ulceration with some giant-cell systems (Pugh and Stringer, 1956; Weinberg, 1946; Mowrey and Lundberg, 1954).

The alimentary tract is but rarely involved in generalized sarcoidosis, the commonest site being the stomach; the lesion is frequently mistaken for a carcinoma of the linitis plastica type (Orie, Van Rijssell and Vanderzwag, I950; Appell, Pritzker and Klotz, 195I). Histologically some cases of Crohn's disease may resemble sarcoidosis but there is no relationship between the two diseases (McKusick, 1953; Phear, 1958).

\section{Experimental Aspects}

In the laboratory, typical granulomatous lesions can occur as part of an immune response. If guinea-pigs or rabbits be sensitized to foreign protein, subsequent subcutaneous injection of the antigen several days later produces a characteristic granulomatous response (Figs. I and 2). Histologically the lesions show histiocytosis, monocytes, endothelial cells and a giant cell and eosinophilic response at the injection site (Goddard, 1947; Goldgraber and Kirsner, 1958). Endothelial and perithelial reactions are marked and the cellular reaction around small blood vessels may be íntense (Fig. 3). Granulomata produced by these means can also be shown to be the site of antibody formation (White, Coons and Connolly, 1955). This

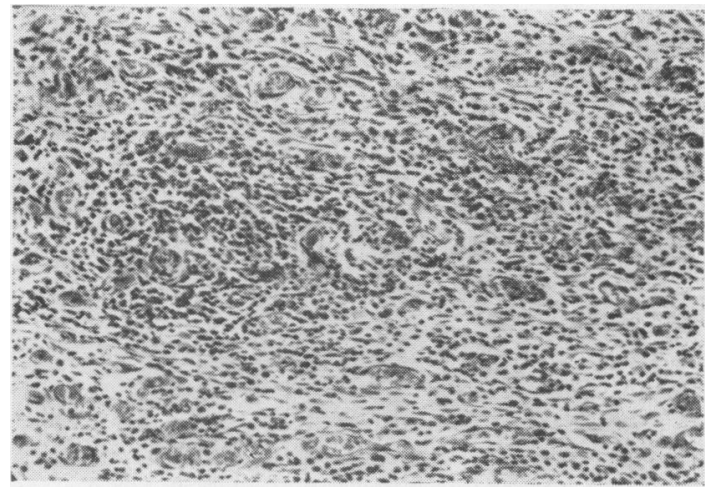

FIG. I

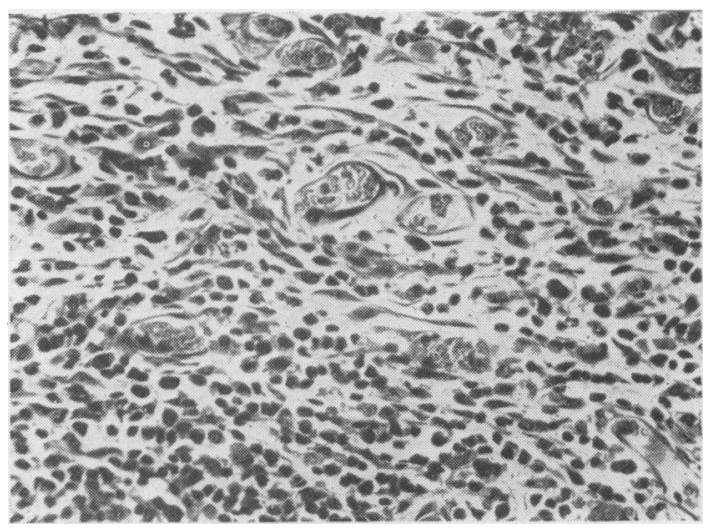

Fig. 2

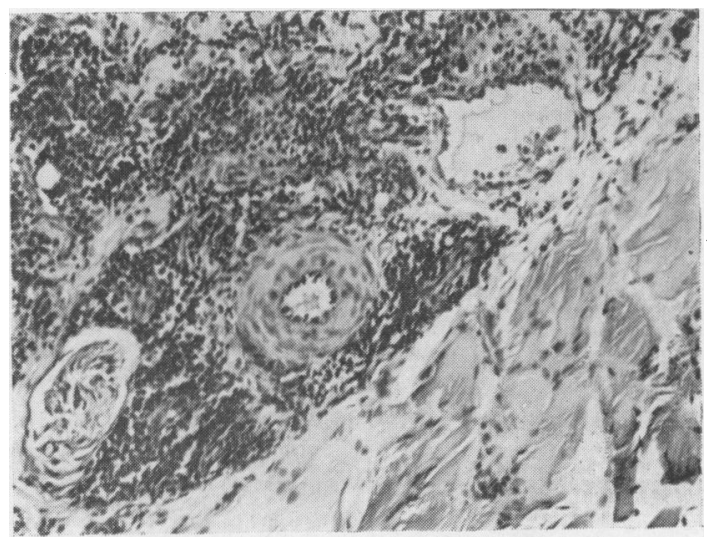

FIG. 3 
was confirmed by the more precise studies of Askonas and Humphrey (1955) who studied the granulomata produced by Freund's adjuvant in rabbits using ${ }^{14} \mathrm{C}$ labelled glycine and showed that the cell mass of the granuloma produces some $80 \%$ of the antibody. There is now very good evidence that plasma cells are one of the main sources of antibody (Gell, 1959). Fagraeus (1948) has shown that many reticulo-endothelial cells develop into plasma cells and in the course of this process antibodies are formed; the main producers of antibody are immature plasma cells for mature plasma cells apparently lose the power of antibody synthesis (Oakley, 1959).

In clinical practice there is also strong evidence indicating that certain granulomata arise as a result of an immune type of response. Shelley and Hurley (1957) demonstrated, both experimentally and clinically, that man can develop granulomatous lesions as a result of generalized hypersensitivity to sodium zirconium lactate. More, McMillan and Duff (1946) reported widespread granulomatous lesions in the heart, liver and kidneys in patients sensitive to sulphonamide. Churg and Strauss (195I) reported 13 cases of severe asthma followed by fever and intense eosinophilia; I I patients subsequently died and widespread granulomatous lesions were present throughout the body with radially arranged macrophages and giant cells; arterial lesions essentially similar to those seen in polyarteritis nodosa were also present.

It will thus be seen that there is strong clinical and experimental evidence indicating the close correlation between the granulomatous response and immune hypersensitive states generally.

\section{The Immune Response in the Alimentary Tract}

Injection or ingestion of proteins into the stomach of previously sensitized animals produces congestion and œdema followed by induration and necrosis; similar changes occur in sensitized dogs (Shapiro and Ivy, 1926; Thiers and Chevallier, 1935). Jahiel and his associates (1952) induced local sensitivity by injecting horse serum into the wall of the stomach and after an interval horse serum was given intravenously; $52 \%$ of the experimental animals developed gastric lesions consisting of localized areas of mucosal and submucosal œdema with lymphocytes, plasma cells and a few eosinophils. In a number of animals actively bleeding lesions with crater formation surrounded by œdema were produced. The Shwartzman phenomenon can occur in the stomach wall under experimental conditions but does not usually produce ulceration (Karsner, Ecker and Jackson, 193I). If any part of the alimentary tract of monkeys be passively sensitized a brisk local reaction occurs when the antigen is given either by mouth or intravenously (Walzer, Gray, Straus and Livingston, 1938).

In human beings it is common for severe anaphylactic reactions to be accompanied by nausea, vomiting and abdominal pain. In patients $\bar{C}$ with known gastro-intestinal allergy, ingestion of $\frac{\overline{\underline{B}}}{\mathrm{E}}$ the causative antigen causes an initial hyperæmia $\frac{\bar{\rho}}{\triangle}$ of the alimentary mucous membrane followed byฉ widespread œdema and a greatly increased production of mucus; local hæmorrhage may occur $\vec{\circ}$ (Pollard and Stuart, I941). Similar lesions may be observed on exposed mucous membrane in $\vec{\omega}$ patients with an ileostomy or a colostomy if local passive sensitivity be induced by intramucosale injection of serum from an allergic individual (Gray, Harten and Walzer, 1940). Oral administration ${ }_{y}$ of the antigen is shortly followed by initial pallor in the sensitized area and subsequent hyperæmia,. progressive œdema and profuse secretion of mucus. N Thus it is clear that the human alimentary tract is $\%$ quite capable of participating in or being involved $\frac{}{2}$ by immune-hypersensitivity reactions.

Goldbraber and Kirsner (1959) have reported an Arthus type reaction in the colon of rabbits sensitized to egg albumin. At a subsequemt $\vec{\varnothing}$ operation egg albumin was injected subserosalf into the colon and granulomata and giant cells weme repeatedly observed six and seven days after the eliciting injection; eosinophils were prominent.

Similar lesions have been produced in the small intestine of rabbits sensitized to horse serum. The rabbits were sensitized by a series of intra- $\stackrel{2}{\vec{F}}$ venous injections and then subsequently operated $\frac{3}{3}$ upon and given subserosal injections of the antigen. After a lapse of several days a pronounced local reaction occurred with the formation of a granuloma; adhesions between loops of 3 bowel were common with thickening of the mesentery and omental adhesions. Histologically, a marked plasma-cell response was usually present $\delta$ with abundant eosinophils; giant-cell systems were frequent and several animals exhibited 0 characteristic granulomata not unlike those some- $D$ times seen in regional enteritis and ulcerative colitis (Figs. 4 and 5). Lymphatic dilatation, however, was not observed in these lesions.

The Shwartzman phenomenon can be produced $N$ in the colon under experimental conditions and a granulomatous response is regularly seen during $\underset{\sigma}{\sigma}$ the healing phase. The Auer type of sensitivity response is a variant of the Arthus, whereby the $\frac{D}{\Phi}$ local reaction is facilitated by previous local irrita- $\stackrel{?}{?}$ tion. This type of reaction has recently been $T$ produced experimentally in the colon and the $\bar{P}$ resulting changes closely resembled those seen in $\mathbb{\mathbb { D }}$ human ulcerative colitis. Moreover, in the $\vec{\nabla}$ 


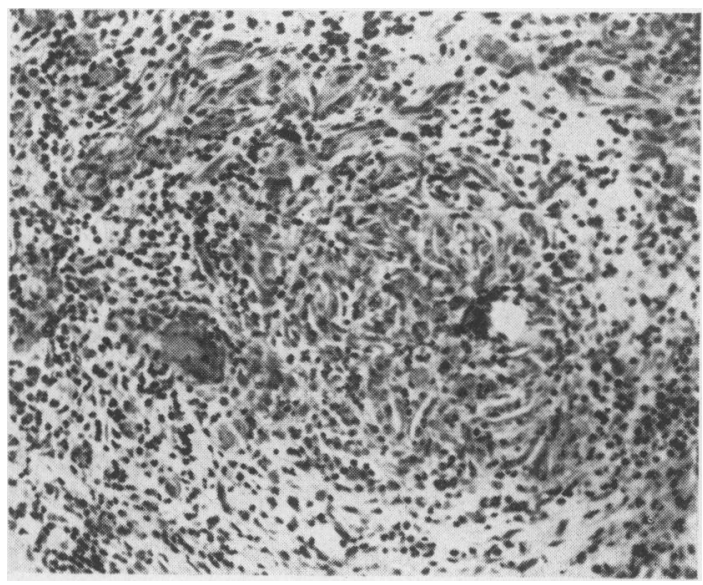

FIG. 4

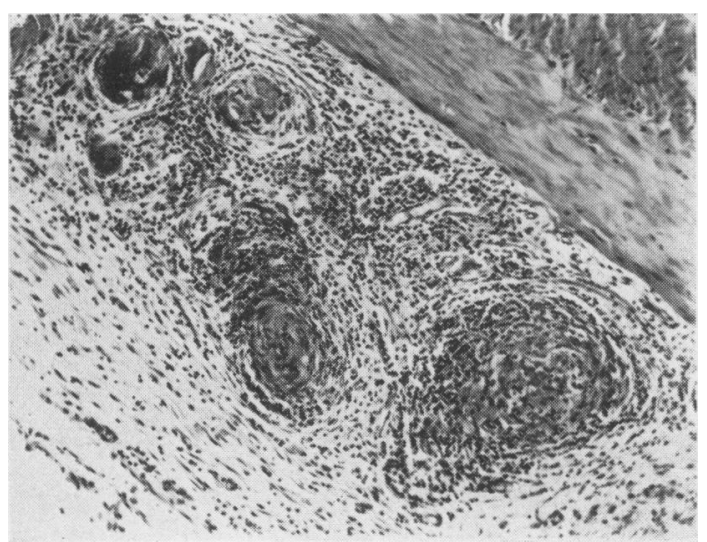

FIG. 5

sensitized animals these lesions were accompanied by a rise in serum gamma-globulin with a fall in serum albumin; alterations of this nature are frequent in ulcerative colitis (Kirsner and Goldgraber, 1960).

It thus seems established that certain diseases in man are due to an immune-hypersensitivity mechanism; furthermore, the human alimentary tract is capable of participating in such a response. The frequent association between granulomata and the immune state, and the demonstration that such lesions can be produced in the alimentary tract experimentally, has led to a great deal of conjecture as to what part, if any, such mechanisms play in the production of the non-specific alimentary granulomata seen in man. It must be stressed that as yet, no valid conclusions can be drawn concerning the relationship between experimentally induced granulomatous lesions and those seen in diseases of the human alimentary tract. Andresen (1940) and Rowe (1942) and Rowe, Rowe and Oyeyama (1953) have stressed the importance of allergic factors in the rtiology of both regional enteritis and ulcerative colitis, but their views have not found wide acceptance and the number of reported cases is small. More recently Truelove (196I) has reported a series of cases of ulcerative colitis provoked by milk or milk products. The not infrequent association of ulcerative colitis with an arthropathy resembling rheumatoid arthritis and its occasional association with disseminated lupus erythematosus and other collagen diseases has given rise to the suggestion that ulcerative colitis may have an immunological basis; at present, however, this remains little more than an interesting speculation. Other phenomena common in hypersensitive states such as alterations in serum globulins, iritis, erythema nodosum and pyoderma gangrenosum are also frequently seen in both regional enteritis and ulcerative colitis and whilst suggestive that immunological factors may be responsible, clear-cut evidence is still lacking.

However, since the evidence is very suggestive that immune factors may be involved in human regional enteritis and ulcerative colitis, numerous endeavours are now being made using precipitin, immunophoretic and hæmagglutination techniques to identify antibodies in these diseases and early successes have been reported. Broberger and Perlmann (1959) demonstrated that the sera of patients suffering from ulcerative colitis contained a precipitating and hæmagglutinating factor reacting against human colon, liver and kidney; this factor was a gamma-globulin. Further studies by others have supported these findings. Polcak and Vokurka (I960) prepared an antigen irom normal colonic mucosa and using a collodion precipitin technique obtained strongly positive results with the sera of 30 patients with ulcerative colitis; in 195 patients with diseases other than ulcerative colitis and in 20 normal patients there was no reaction at all.

Despite these encouraging initial reports, however, the hypothesis that diseases such as regional enteritis and ulcerative colitis are immune disorders still remains to be proved and a great deal of knowledge has yet to be obtained before this fascinating problem is finally solved. 


\section{REFERENCES}

Abrams, H. L., Carnes, W. H., and Eaton, J. (1954): Alimentary Tract in Disseminated Scleroderma with Emphasi on Small Bowel, Arch. intern. Med., 94, 6r.

Andresen, A. F. R. (1940): The Surgeon and Colonic Allergy, Amer. F. Surg., 50, 281.

Appell, A. A., Pritzker, H. G., and Klotz, P. G. (195I): Pyloric Obstruction due to Sarcoid of the Stomach, A.M. $A_{\complement}$ Arch. Surg., 62, 140.

Askonas, B. A.. and Humphrey, J. H. (1955): Antibody Formation in Slices of Granulomata Produced by Adjuvant Biochem. F. (Lond.), 60, 10.

Broberger, O., and Perlmann, P. (1959): Auto-antibodies in Human Ulcerative Colitis, F. exp. Med., r1o, 657.

ChURG, J., and Strauss, L. (195 I): Allergic Granulomatosis, Allergic Arteritis and Peri-arteritis Nodosa, Amer.. . Path. $27,277$.

Codman, G. C., and Churg, J. (1954): Wegener's Granulomatosis, Arch. Path., 58, 533.

Curtis, A. C., Blaylock, H. C., and Harrell, E. R. (1952): Malignant Lesions Associated with Dermatomyositis F. Amer. med. Ass., 150, 844 .

Domzalski, C. A., and Morgan, V. C. (1955): Dermatomyositis, Amer. Y. Med., 19, 370.

Dowling, G. B. (1955): Scleroderma and Dermatomyositis, Brit. $\mathcal{~}$. Derm., 67, 275 .

Dubois, E. L. (1953): Effect of the L.E. Cell Test on the Clinical Picture of Systemic Lupus Erythematosus, Ann. intern Med., 38, 1265 .

Fagraeus, A. (1948): Antibody Production in Relation to the Development of Plasma Cells, Acta med. scand. Suppl., 204.

FELSON, B., and BRAUNSTEIN, H. (I958): Non-infectious Necrotising Granulomatosis, Radilogy, $70,326$.

GajDuseK, D. C. (1958): An Auto-immune Reaction against Human Tissue Antigens in Certain Acute and Chronic Diseases. I. Serological Investigations, Arch. intern. Med., roI, 9.

GeLL, P. G. H. (1959): Cytologic Events in Hypersensitivity Reactions, in Cellular and Humoral Aspects of the Hypersensitive States. New York: Hoeber-Harper.

GeRMUTH, F. G. (1953): A Comparative Histologic and Immunologic Study in Rabbits of Induced Hypersensitivity of the Serum Sickness Type, $\mathcal{F}$. exp. Med., 97, 257.

GodDARD, J. W. (1947): Granuloma. Characteristic Qualitative Change in Focal Anaphylactic Inflammation; Amer. YO

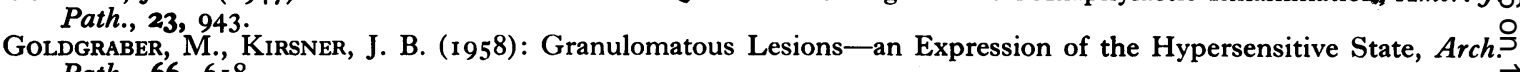
Path., 66, 618.

- , (1959): The Arthus Phenomenon in the Colon of Rabbits, Arch. Path., 67, 556.

Gray, I., HARTEN, M., and WALZER, M. (1940): Studies in Mucous Membrane Hypersensitiveness. IV. The Allergie Reaction in the Passively Sensitized Mucous Membranes of the Ileum and Colon in Humans, Ann. intern. Med., 13, 2050.

Hale, C. H., Schatzki, R. (1944): The Roentgenological Appearance of the Gastrointestinal Tract in Sclerodernea,

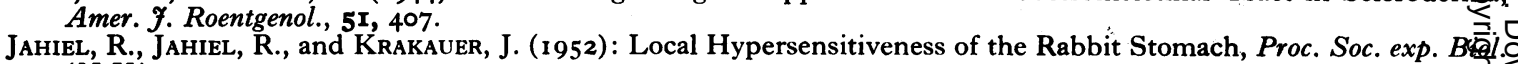
$(N . Y$.), 79, 54 .

Karsner, H. T., ECKer, E. E., and Jackson, E. L. (1931): Shwartzman Phenomenon in the Rabbit Stomach, Proc. Soc. exp. Biol. (N.Y.), 29, 319.

KIRSNER, J. B., and GolDGRABER, M. B. (1960): Hypersensitivity, Auto-immunity and the Digestive Tract, Gastroenterology, 38,536 .

LUI, C. T., and MCCRORY, W. W. (1958): Auto-antibodies in Human Glomerulonephritis and Nephrotic Syndrome f. Immunol., 81, 492.

Lushbaugh, C. C., Rubin, L., and Rothman, S. (1948): Scleroderma of the Gastro-intestinal Tract; First Report of a Fatal Case, Gastroenterology, II, 382.

MACKAY, I. R. (1958): Primary Biliary Cirrhosis Showing a High Titer of Auto-antibody, New Engl. F. Med., 258, r85

McKusicK, V. A. (1953): Boeck's Sarcoid of the Stomach with Comments on the Ætiology of Regional Enteritis, Gastroenterology, 23, 103.

More, J. H., McMillan, G. C., and Duff, G. L. (1946): The Pathology of Sulphonamide Allergy in Man, Amer. $\mathcal{Y} .0$ Path., 22, 703 .

Mowrey, F. H., and Lundberg, E. A. (1954): Clinical Manifestations of Essential Polyangitis, Ann. intern. Med., 40. I I 45.

OAKLEY, C. L. (1959): The Localisation of Antibody Production, in Modern Trends in Pathology. Ed. Collins, D. H. London: Butterworth.

Orie, N. G. M., Van Rijssel, T. G., and Vanderzwag, G. L. (1950): Pyloric Stenosis in Sarcoidosis, Acta med. scand.? 138, 139 .

Phear, D. N. (1958): The Relationship between Sarcoidosis and Regional Ileitis, Lancet, ii, 1250.

Polcak, J. and Vokurka, V. (1960): Auto-immune Reactions in the Course of Ulcerative Colitis, Amer. F. dig. Dis., 5, N 395 .

Pollard, H. M., and Stuart, G. J. (194I): Experimental Reproduction of Gastric Allergy in Human Beings withn Controlled Observations on the Mucosa, F. Allergy, 13, 467.

Pugh, J. I., and Stringer, P. (1956): Abdominal Peri-arteritis Nodosa, Brit. F. Surg., 44, 303.

RefVem, O. (1954): Pathogenesis of Boeck's Disease, Acta med. scand. Suppl., 294.

RICH, A. R. (1942): Role of Hypersensitivity in Peri-arteritis Nodosa, Bull. Fohns Hopk. Hosp., 71, 123.

Rosenthal, F. D. (1957): Small Intestine Lesions with Steatorrhœa in Diffuse Systemic Sclerosis, Gastroenterology, 32, 332.

Rowe, A. H. (1942): Chronic Ulcerative Colitis. Allergy in its Aetiology, Ann. intern. Med., 17, 83.

-, Rowe, A., and Uyeyama, K. (1953): Regional Enteritis-its Allergic Aspects, Gastroenterology, 23, 554.

Shapiro, P. F., and Ivy, A. C. (1926): Gastric Ulcer IV. Experimental Production of Gastric Ulcer by Local Anaphylaxis, Arch. intern. Med., 38, 237. 
Shelley, W. B., and Hurley, H. J. (1957): Experimental Evidence for an Allergic Basis for Granuloma Formation in Man, Nature, 180, 1060.

Thiers, H., and CHevallieR, R. (1935): Les Lésions Macroscopiques du Choc Anaphylactique par Ingestion, chez le Cobaye Sensibilisé par voie Parentérale, C.R. Soc. Biol. (Paris), 120, 1009.

Truelove, S. C. (r96r): Ulcerative Colitis Provoked by Milk, Brit. med. F., I, 154.

VAzQuez, J. J., and Dixon, F. J. (1957): Immuno-histochemical Study of Lesions in Rheumatic Fever, Systemic Lupus Erythematosus and Rheumatoid Arthritis, Lab. Investigation, 6, 205.

Wainger, C. K., and Lever, W. F. (1949): Dermatomyositis, Arch. Derm. Syph. (Chicago), $59,196$.

Walton, E. W. (1958): Giant Cell Granuloma of the Respiratory Tract (Wegener's Granulomatosis), Brit. med. $\mathcal{F}$., $2,265$.

Walzfr, M., Gray, I., Straus, H. W., and Livingston, S. (1938): Studies in Experimental Hypersensitiveness in the

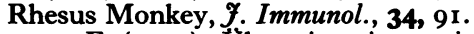

WEGENER, F. (1939): Über eine eigenartige rhinogene Granulomatose mit besonderer Beteiligung des Arterien systems und der Nieren, Beitr. path. Anat., 102, 36.

Weinberg, T. (1946): Peri-arteritis Nodosa in Granuloma of Unknown Aetiology, Amer. F. clin. Path., I6, 787.

White, R. G., Coons, A. H., and Connolly, J. (r955): Studies on Antibody Production. III. The Alum Granuloma, F. $\exp$. Med., 102, 73 .

Witebsky, E., Rose, N. R., Terplan, K., Paine, J. R., and Egan, R. W. (1957): Chronic Thyroiditis and Autoimmunisation, f. Amer. med. Ass., 164, 1439. , and Shulman, S. (1958): The Auto-antibody Nature of the Thyroiditis Antibody and the Role of Thyroglobulin in the Reaction, Lancet, i, 808 . 